\title{
THE OBLIGATION OF THE CONSTITUTIONAL COURT OF INDONESIA TO GIVE CONSIDERATION IN THE PROCESS OF DISSOLUTION OF SOCIETAL ORGANIZATIONS
}

\author{
Putra Perdana Ahmad Saifulloh \\ Faculty of Law, Bhayangkara University, Jakarta Raya \\ putrappas@gmail.com
}

\begin{abstract}
The government efforts to dissolve the societal organizations must be carried out in accordance of stages and processes stipulated in the Law on Societal Organizations. Persuasive efforts must be done first before the imposition of administrative sanctions. Administrative sanctions in the form of warning letters and temporary suspensions of activities need to be done before the Government dissolves the societal organizations after a court decision was obtained from the permanent legal force. The writer considered that the dissolution of societal organizations by the Government was urgent for the present, but the Government before dissolving societal organizations should seek consideration from the Constitutional Court of Indonesia as the guardian, and interpreter of Pancasila. Thus, the Constitutional Court of Indonesia as a neutral judicial institution shall have the authority to consider whether a societal organization will be dissolved.

Keywords: Constitutional Court of Indonesia, Dissolution of Societal Organizations, Pancasila
\end{abstract}

\section{INTRODUCTION}

\subsection{Background}

Article 28 of the 1945 Constitution of the State of the Republic of Indonesia (Hereafter mentioned as the 1945 Constitution) which states that "freedom of associate and assembly, expulsion of thought orally and written and so on is stipulated by law", is a constitutional basis for union activities, assembly, and 
issues thought both oral and written. On the basis of constitutional basis regarding freedom of association and assembly, human as social beings are given the rights to live in a group whether permanently or temporally which in the 1945 Constitution is given the terms of association or assembly. The fundamental provisions of association form a constitutional basis for establishing organizations in Indonesia. Currently known as socio-political organization and community organization which consist of professional and functional organization also various non-governmental organizations. This modern organization enables the effective and efficient organization of the people's sovereignty. ${ }^{1}$

Freedom of expression is governed in Article 28E paragraph (3) of the 1945 Constitution which states that, each person is entitled to freedom of association, assembly and expression. Freedom of expression includes the rights to seek, receive, and disseminated ideas and information in channelling aspirations. This freedom is a multi-faceted right which shows the breadth and extend of human rights law. This gives consequences that each human action or groups is not unlimited. There should be steps to ensure that freedom of expression does not harm rights and freedoms of others. ${ }^{2}$ That one of the implementation of freedom of association and assembly, the Government considers it necessary to draft a law based on the provisions of 1945 Constitution before the reform, namely Law No. 8 of 1985 on Societal Organization, and the current Law No. 17 of 2013,3 which was passed on July 22, 2013.4

Through Law No. 17 of 2013 on Societal Organization, the existence of societal organization obtains a number of restrictions, especially ideology restriction that require Pancasila as the societal organizations ideology to the imposition of sanctions for societal organizations committing certain offences. Societal organizations can be defined generally as a group of people joining on the basis

1 Nia Kania Winayanti, Dasar Hukum Pendirian dan Pembubaran Ormas (Organisasi Kemasyarakatan) (Yogyakarta: Pustaka Yustisia, 2011), 11-28.

2 Suparman Marzuki, et.al, Hukum Hak Asasi Manusia (Yogyakarta: Pusat Studi Hak Asasi Manusia, Universitas Islam Indonesia, 2008), 100-101.

3 The author wrote this paper when the Law No.17 of 2013 is still a positive law for the regulation of Societal organization.

4 Pan Mohammad Faiz, "The Protection Of Civil and Political Right By The Constituttional Court of Indonesia", Indonesia Law Review Journal 6, no. 2 (May-August 2016): 163. 
of a common vision, orientation, and political perception. Those three things give birth to a certain value that commonly referred as "ideology". ${ }^{5}$ Ideology is generally a system of beliefs held by society to organize themselves. ${ }^{6}$ Ideology also can be regarded as a comprehensive vision, as a way to view something. ${ }^{7}$ The ideology is set forth in a constitution of organization known as the Statutes, which are then elaborate in detail in the platform of societal organizations struggles, which are illustrated in the bylaws. ${ }^{8}$ Ideology is a collective value that will affect the attitudes and behaviour of members, so that from the position, attitude, and behaviour of a person, should be expected from which organization they were. ${ }^{9}$

One of the reason for the dissolution of societal organizations in Indonesia is if activities of a societal organization strongly indicated against goals, principles, and characteristics that based on Pancasila and the 1945 Constitution. The most recent significant event was when government dissolved a societal organizations named Hizbut Tahrir Indonesia (hereafter mentioned as HTI), because this societal organization was seen not to carry out a positive role in the development process in order to achieve national goals. HTI activities were also strongly indicated had an opposite goals, principles, and characteristics of stated which based on Pancasila and the 1945 Constitution. The Government through the Coordinating Minister of Political, Legal, and Security affairs (Menkopolhukan) Wiranto, on May 12, 2017, stated the Governments' stance that would dissolve a Societal Organization that threatening the existence of the Unitary State of the Republic of Indonesia (NKRI). Any societal organization that intends to threaten the existence of NKRI, including HTI, would be dissolve through legal channels. ${ }^{10}$ The Attorney General's Office through Attorney General HM Prasetyo stated that the demands for the dissolution of HTI to the court would be made after receiving all the evidence. Currently all the evidence is said to be still in the Police, the Ministry of Home Affairs, and the Ministry of Justice and Human

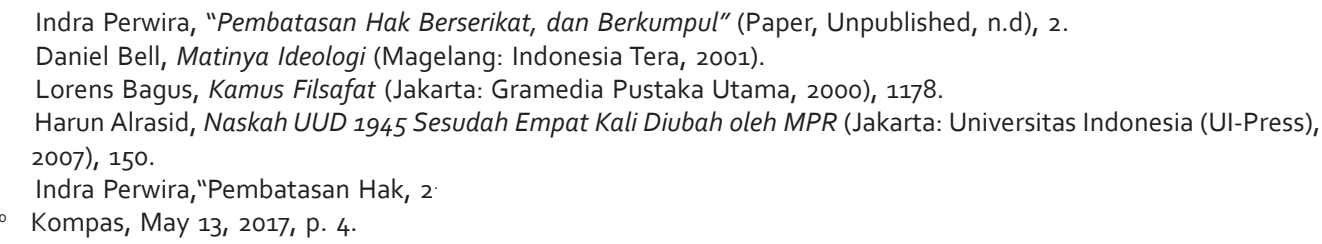


Rights. Regarding this matter, the police have confirmed to have a video proof and documentation that HTI is in conflict with Pancasila, among them was HTI activities in one of campus in West Java."

Discourse around the dissolution of HTI as societal organization was still rolling in the community. As a state of law, ${ }^{12}$ the Government should always base its policies on the basis of applicable law, ${ }^{13}$ and in its applications, should uphold the state democratic process, ${ }^{14}$ because it aims to protect human right. ${ }^{15}$ Similarly, in this case, the Governments' efforts to dissolve the HTI societal organization should go through processes and stages in accordance to the applicable law. In Article 6o to Article 82 of Law No. 17 of 2013 stipulates the sanctions for societal organization whose actions are in conflicts with Pancasila, and the 1945 Constitution from the awarding of warning letters up to three times; cessation of assistance; freezing; and dissolution through the judicial mechanism.

However, it will take a long time if the Government comply to the positive law about the dissolution of societal organizations, while the state should not allow any societal organization that act against the Pancasila as the state ideology exists in Indonesia. For these reasons, the author is interested to write about the dissolution of societal organization that fits the concept of democracy legal state, but also prioritize the effectiveness and time efficiency. The author considered that the dissolution of societal organization by the Government was something urgent for now, but before dissolving any societal organization the Government should seek consideration from the Constitutional Court of Indonesia as a guardian and interpreter of Pancasila. Therefore, the Constitutional Court as a neutral judiciary has the authority to consider whether societal organizations will be dissolved or not. Based on the basic description above, the author is interested to write a paper

\footnotetext{
Media Indonesia, May 15, 2017, p. 8.

12 Padmo Wahjono, Indonesia Negara Berdasarkan atas Hukum (Jakarta: Ghalia Indah, 1986), 1.

${ }_{13}$ Hendra Nurtjahjo (Ed), Politik Hukum Tata Negara Indonesia (Jakarta: Pusat Studi Hukum Tata Negara Fakultas Hukum Universitas Indonesia, 2004), 277.

14 Muhammad Tahir Azhary, Beberapa Aspek Hukum Tata Negara, Hukum Pidana, dan Hukum Islam: Menyambut 73 Tahun Prof. Dr. H. Muhammad Tahir Azhary, S.H., Akademisi, Praktisi, dan Politisi (Jakarta: Kencana Prenada Media Group, 2012), 28-29.

15 Philipus M Hadjon, Perlindungan Hukum Bagi Rakyat di Indonesia (Surabaya: Bina IImu, 1987), 71.
} 
which entitled "The Obligation of the Constitutional Court to Give Consideration in the Process of Dissolution of Societal Organizations", with the formulation of the problems: (1) Why does the Law on Societal Organizations require every societal organization in Indonesia to comply with Ideology Pancasila, (2) What are the process of sanctioning up to dissolution of Societal Organizations based on in Law No. 17 of 2013 on Societal Organizations; (3) How is the possibility of dissolution of societal organization become the authority of the Government, and the Obligation of the Constitutional Court to give consideration in the Process of Dissolution of Societal Organization becomes new authority for the Constitutional Court.

\subsection{Research Method}

This research is a normative legal research which uses doctrinal method in analyzing principles and norms of legislation relating to the process of dissolution of societal organization. Normative legal research conceptualize the principles and doctrines as well as a set of norms in the legislation, in this case the norms related to the obligation of the Constitutional Court to give consideration in the process of dissolution of societal organization. There are four approaches used in this study, namely: statute approach, historical approach, case approach and conceptual approach.

Primary legal materials includeL: (1) the 1945 Constitution of the Republic of Indonesia; (2) Law No.17 of 2013 on Societal Organization. Secondary legal materials which include: Minutes of discussion of the amendment of the 1945 Constitution, bill on the Constitutional Court and the its minutes of discussion, bill on the societal organizationand it's minutes of discussion, and the decisions of the Constitutional Court and the decisions of other courts, research papers, law journals, other scholarly works. While tertiary legal materials, namely, among others are dictionaries and encyclopedias. 


\section{ANALYSIS}

\subsection{Societal Organization and Pancasila Ideology}

In viewing the original intent (means and purposes) establishment, and the discussion process of societal organization law. The author need to examine the political configuration in the minutes of meeting of the formation of the societal organization law, especially the regulation of Pancasila as the only principles for all societal organization in Indonesia.

The concept of the sole principle of Pancasila begins with the speeches of President Soeharto in Pekanbaru, Riau, in the Opening of the National Military Forces' (ABRI) leader meeting on March 27, 1980, and the birthday of the Special Forces Command (Kopassus) 16, 1980. In both speeches President Soeharto wants Pancasila and the 1945 Constitution become the foundation of society life, nation, and state. Therefore, that Pancasila is not abused, and undermined by various forces, both extreme left and extreme right. The Plenary Session of Parliament on August 16, 1980 reaffirmed the necessity of a single principle of Pancasila for social and political forces in Indonesia. ${ }^{16}$

The policy on the single principle of Pancasila in the party system in Indonesia was first published in MPR Decree No. II/MPR/1983 on the Guidelines of the State Policy (GBHN), which state that: ${ }^{17}$

To strengthen the stability in the political field, efforts must be made to strengthen the unity of the nation, as well as the growth of a constitutional, democratic, and law-based life based on the 1945 Constitution. In this framework, and the preservation, and practice of Pancasila, social political forces particularly Political Parties, and the Working Group (GOLKAR), and Social Organizations must be truly a social-political force that only stipulates Pancasila as the only principle.

16 Lili Romli, Islam Yes Partai Islam Yes: Sejarah Perkembangan Partai-Partai Islam di Indonesia (Yogyakarta: Pustaka Pelajar dengan Pusat Penelitian Politik LIPI, 2006), 68.

17 Direktorat Jenderal Pendidikan Tinggi Departemen Pendidikan, dan Kebudayaan, UUD 1945, P4, GBHN, TAP-TAP MAPR 1983, Pidato Pertanggungjawaban Presiden/Mandataris, Bahan Penataran, dan Bahan Referensi Penataran (Jakarta: Direktorat Jenderal Pendidikan Tinggi Departemen Pendidikan, dan Kebudayaan, 1984), 107. 
That policy explained by President Soeharto as follows: $:^{18}$

If the socio-political forces have used Pancasila as the only principles, in the future, all socio-political forces will compete to offer the best idea, and figures that are as competent to their people in the great race of great development as the practice of Pancasila in order to achieve the national goal. Since all political forces have publicly affirmed Pancasila as the only principle, it would be easily prevented, and avoided to sharpening the opposition of groups in the pursuit of their respective goals which resulting in clashes, endangering unity, and national unity.

With the affirmation of all socio-political forces concerning the only principles of Pancasila they used, on the other hand we will all be free from the remnants of mutual suspicion, and the mutual worry that has grown due to real experiences in the past; and on the other hand, the disappearance of mutual suspicion, and the mutual worry will refresh the growth of Pancasila democracy.

With Pancasila as the only principle, it did not mean that we will ignore or degrade our level in an effort to develop religious life in Indonesia. Instead, we will develop the best relationship between religious life, and political life in Indonesian society.

Religions were a source of motivations, and inspirations to their adherents, to a responsible citizen for imposing their choices on existing social and political forces, all of which used Pancasila as the only principles. Thus, any religion that exists in Indonesia could provide a basis of ethic, and a strong moral to political life.

Thus, the understanding of the policy on the single principles of Pancasila above was the Governments' attempt to eliminate the ideology of societal organization in Indonesia, namely abolish any other principles outside of Pancasila. ${ }^{19}$ According to Moh. Mahfud MD, Suharto's steps to emasculate the societal organizations were an attempt by Soeharto to make the New Order become a strong state. The main steps to make the New Order become a strong state were engaged in the Law on Political Party, the Working Group (GOLKAR), ${ }^{20}$ and Societal Organization which later regulates and requires every political party, and Societal Organizations in Indonesia to adopt single-based Pancasila.

18 Suara Merdeka, August 16, 1984, p. 13-14.

19 Sugeng Priyanto, Dinamika Ideologi Partai Politik Keagamaan Pada Masa Orde Baru (Yogyakarta: Magnum Pustaka Utama, 2015), 117.

20 Moh. Mahfud. M.D, Politik Hukum di Indonesia (Jakarta: Rajawali Pers, 2010), 214. 
The first Law that requires Pancasila as the sole principle for every political party in Indonesia is Law No. 8 of 1985 on Societal Organizations. It was a proposal from the Government, where in Article 1 No. 2 section (1) states: "Societal Organization based on Pancasila as the only principle". To knew why the legislators made Pancasila as the only principles for every political party in Indonesia. The author need to examine the original intent formation, and the discussion process of Law No.8 of 1985. In the First Meeting, the Chairman of the Special Committee on the fifth draft of Law on Politics, Suhardiman said:21

In line with the mandate of MPR Decree No. II/MPR/1983 on the Guidelines of the State Policy (GBHN), Political Parties, and the Working Groups should be based on Pancasila as the only principles. The Special Committee, the Government will not create a new Law about Political Parties, and the Working Group (GOLKAR), and Social Organizations, but want to improve and strengthen the political life structure in Indonesia based on Pancasila as the only principle.

Nurhasan Ibnuhadjar as the representation of the United Development Faction gave his general view states: ${ }^{22}$

Regarding the matter of principle, our faction believes that there is nothing more to be questioned. In our party congress held in August 1984, the principles of Pancasila as the only principle has been accepted, in which it has been incorporated into the Party's political parties and social organization.

Ibnuhadjar's opinion was strengthened further by Sugandhi Kartosubroto who represented the Development Work Faction. He states "Organization of sociopolitical forces is an organization of individual cadres, holding onto Pancasila as the only principle and oriented to the national development program". ${ }^{23}$

The Military in the Parliament was the most assertive and consistence faction in supporting Pancasila as the only principle as proven by the mini-general view of the faction represented by Harsono by stating: "The military holds the Pancasila as the only principles for Political Parties. The Working Group, and the

\footnotetext{
Dewan Perwakilan Rakyat RI, Catatan Panitia Khusus Lima Rancangan Undang-Undang Tentang Politik, Tanggal 10 January 10, 1985 (Jakarta: Sekretariat Jenderal DPR RI, 1985), 2.

22 Ibid, p. 6.

23 Ibid, p. 12.
} 
Societal Organization are a must that cannot be delayed any longer". ${ }^{24}$ Given that the three factions in the House of Representatives had approved Pancasila as the only principles, the Indonesian Democratic Party fraction had no choice but to approve what the Government proposed which has been supported by F-PP, F-KP, and F-ABRI. This was demonstrated by the attitude of F-PDI represented by Adipramoto which states "Political Parties, and the Working Groups (GOLKAR), and Societal Organizations must really become a socio-political force based on Pancasila as the only principle". 25

In the second session, the Government represented by the Minister of the Interior, Supardjo Rustam asserted: "For the sake of sustainability, and the practice of Pancasila, the social and political forces in Indonesia, especially Political Parties, and the Working Group (GOLKAR), and the Societal Organization must really become socio-political forces that based on Pancasila as the only principle". ${ }^{26} \mathrm{UP}$ to the last hearing, in the $5^{\text {th }}$ session of the Political Party Law, the attitude of all factions in the House of Representatives, as well as the Government remained unchange or the current language of the House of Representatives was "not to the cold" consistently supportive, and Pancasila as the only principle. ${ }^{27}$ The Political Party Law was numbered by the State Secretariat as Law No. 8 of 1985, signed by the President, and included in the State Gazette of June 19, 1985.

After analysing the original intent of the minutes of the establishment of Law No. 8 of 1985, the author concluded that the House of Representatives and the Government agreed to make Pancasila as the sole principle for every political parties in Indonesia. Its purpose is solely for the national stability, i.e. to prevent and to avoid any conflicts between groups in efforts to achieve their respective goals resulting in clashes, endangers national unity.

According to Mahfud MD, the fifth package of Law on Politics was an orthodox/elitist/conservative legal product because the objectives of the New

24 Ibid, p. 27.

25 Ibid, p. 19.

26 Dewan Perwakilan Rakyat RI, Catatan Rapat Panitia Khusus Lima Rancangan Undang-Undang Partai Politik, dan Golongan Karya, February 4, 1985 (Jakarta: Sekretariat Jenderal DPR RI, 1985), 10.

27 Dewan Perwakilan Rakyat RI, Catatan Panitia Khusus Lima Rancangan Undang-Undang Tentang Politik, Tanggal 11 Januari 1985 (Jakarta: Sekretariat Jenderal DPR RI, 1985), 1-12. 
Order Government were to create a strong Government that could guarantee the national stability in order to carry out the development that heavily depends on the economy to have a stable political atmosphere. The New Order Government used to control the opposition in a repressive way, but the New Order Government wrapped those repressive measures in a constitutional way through the limitation of political democracy, one of them by uniform the ideology for every Societal Organization in Indonesia. ${ }^{28}$

The obligation of political party to adopt Pancasila as an ideology was a restriction of rights and freedoms in accordance with the principle of rule of law prevailing in Indonesia. In this case, supervision towards the principles of societal organization was one form of constitutional restriction implemented by the state. The ideology of Pancasila was first emphasized as the only principle for Societal Organization in the decree of People's Consultative Assembly (TAP MPR) No. II/MPR/1983 and Law No. 8 of 1985. In the Law of Societal Organization in the reform era, the legislators still consider Pancasila as a plenary ideology for the principles of societal organization.

\subsection{Sanctions and Dissolution of Societal Organizations}

On July 11, 1945, the investigating Committee for Preparatory Work of Independence (BPUPK) decided to set up a small committee to design a new. ${ }^{29}$ The Constitution draft made by the Small Committee on July 13 was presented in a meeting by the chairman of the small committee, Soepomo. In the draft of the Constitution, several rights have been ruled, namely the right of equal status in law and government (Article 28 paragraph (1)), the right to work and a decent live for humanity (Article 28 paragraph (2)), the right of freedom of religion and worship (Article 29), the right to participate in state defence (Article 30 paragraph $(1) .^{30}$

28 Moh. Mahfud. M.D, Politik Hukum di Indonesia, Op.cit, p. 225-313.

29 Saafroedin Bahar, et.al, (Ed), Risalah Sidang Badan Penyelenggara Usaha Persiapan Kemerdekaan Indonesia (BPUPKI)-Panitia Persiapan Kemerdekaan Indonesia (PPKI) 28 Mei 1945-22 Agustus 1945 (Jakarta: Sekretariat Negara Republik Indonesia, 1995), 222.

so Ibid., p. 231. 
In a meeting in July 15 1945, two different opinions emerged regarding the urgency of the inclusion of the right to association and freedom of thought. With the approval of freedom of association and assembly the guarantee of rights were enshrined in the 1945 Constitution, namely in Article 27 paragraph (1) and (2) of the 1945 Constitution before the amendments. After the amendments of the 1945 Constitution, guarantees of human rights are regulated and guaranteed more, namely in the Article 28, Article 28A until 28J of the 1945 Constitution. In addition, the independence proclaimed on August 17, 1945 was a reflection of the strong desire of the Indonesian nation to escape the shackles of colonialism. One of the concretizations of the liberation was the recognitions of people rights in the life of society, nation, and state. The rights known to the public was the active participation of the people in certain activities, for example people can gather in a political party, labour union, and societal organization. ${ }^{31}$

Such participations are essentially an implementation of human rights both in a context of constitution as well as within a scope of profession. Human rights in a scope of profession can be realized in a freedom of association, for example the development and protection of tangible in the form of political parties. Furthermore, both human rights in a context of constitution as well as within the context of profession, are in fact based on the same value, regulated in the Article 28 of the 1945 Constitution about freedom of association and assembly. In a context of participation, further interpretation of the meaning of participation is that each citizen has a voice in the formulation of decision, either directly or through intermediation of levitate institutions representing their interests. This participation is built based on a freedom of association and participate constructively. ${ }^{32}$

In a context of history, human rights are not simply and easily obtained, but it should be achieved through long struggle and tortuous paths. This means that the path taken to achieve the recognition of human rights cannot be separated

\footnotetext{
${ }^{31}$ Nia Kania Winayanti, "Makna Pasal 28 UUD 1945 terhadap Kebebasan Berserikat dalam Konteks Hubungan Industrial," Jurnal Konstitusi 8, no.6 (Desember 2011): 1.

32 Riant D. Nugroho, Kebijakan Publik, Formulasi, Implementasi dan Evaluasi (Jakarta: Elex Media Komputindo, 2003), 219 .
} 
from the beginning of the growth of the idea of human rights it self, as an important phase in the history of state administration. ${ }^{33}$ Although the nature and notions of human have emerged and coloured the nation lives for centuries, but concretely the manifestations have only begun since Magna Charta in 1215. This Magna Charta Charter, brought the revolution in English and the recognition of the rights for each people without exception. ${ }^{34}$ Thus, the concept of human rights arose from the struggle between the elite interests within the state and the community within the state concerned. This means that the history of human rights begins with the demands of liberations from the arbitrary acts of a state against its people. According to John Locke, the concept of human rights is naturally existed and privately owned, namely: the right to life, the right of freedom, the right to property, and the right to own something. 35

Freedom of association was born from the basic human tendency to organize their life. In the view of John Locke and J.J Rousseau, the organizational tendency arises to meet the common needs and interests of individuals to achieve common goals based on equality of thought and consciences. Therefore, the development of freedom of association become one of the fundamental freedoms of human being recognized universally as a part of human rights with the terms of freedom of association. According to Richard H. Pildes, without the freedom of association, the dignity of humanity can be reduced because by itself one cannot express their opinions according to their belief and conscience. ${ }^{36}$

The international recognition on freedom of association is confirmed in Article 20 of Universal Declaration of Human Rights, Article 21 and 22 of The International Covenant on Civil and Political Rights, and Article $5 \mathrm{~d}$ (ix) of The Covenant on the Eradication of Racial Discrimination. Freedom of association is increasingly important as it relates with the recognition of political rights such

\footnotetext{
Soewargo Kartodihardjo, Asas-Asas Hukum Tata Negara (Yogyakarta: Fakultas Hukum Universitas Gajah Mada, 1983),181.

4 SM Amin, Demokrasi Selayang Pandang (Jakarta: Pradnya Paramita, 1976), 44.

Soehino, Ilmu Negara (Yogyakarta: Liberty, 1980), 108.

${ }^{36}$ Muchamad Ali Safa'at, "Pembubaran Partai Politik di Indonesia (Analisis Pengaturan Hukum dan Praktik Pembubaran Partai Politik 1959-2004)" (Dissertasion Doctoral Program of Law, 2009), 16.
} 
as the right to vote, the right of association, the right of free speech, and the right to political equality. ${ }^{37}$

Article 28 of the of the 1945 Constitution states "freedom of associate and assembly, expulsion of thought orally and written and so on is stipulated by law". For implementing this provision, the Government considers that it is necessary to draft a law based on the provisions of 1945 Constitution before the reform, namely Law No. 8 of 1985 on Societal Organization, and the current Law No. 17 of 2013 which was passed on July 22, 2013.

In the normative concept of societal organization, Law No. 17 of 2013 on Social Organization does not regulate the establishment of organization either legal entities, such as associations, foundations, foreign foundations, or non-legal organizations. These legal entities have different set of procedures, requirements, and endorsements. Arrangements on the freezing and dissolution of societal organization are set out in Chapter XVII on sanctions against societal organization that violate the prohibitions set out in the Law No. 17 of 2013.

Prohibition against Societal organization as stipulated in Article 59 of Law No. 17 of 2013 is based on:

a. The prohibitions of the use of flags, emblems, attributes similar to flags, emblems of the Republic of Indonesia, Government agencies, international agencies, forbidden organizations or political parties.

b. The prohibition against committing acts that disturb public securities and public order, including: committing hostile acts against tribes, religions, races, or classes; engaging any separatist activities that threaten the sovereignty of the Unitary State of the Republic of Indonesia; committing acts of violence, disturb public order or tranquility, or damaging public facilities and social facilities.

c. The prohibition to receive donations of any kinds, including the prohibition to raise funds for political parties. Article 20 of the Government Regulation No. 18 of 1986 on the implementation of Law No. 8 of 1985 on Societal Organization explained that societal organizations are prohibited from receiving foreign assistance without central approval and/or providing assistance to foreign parties. The foreign assistance includes financial assistance, equipment, manpower, and facilities.

37 Ibid, p. 16. 
d. The prohibition to develop, embraces, and disseminate doctrines or understanding that contradicts Pancasila.

Arrangements on the prohibitions of this societal organization are intended to anticipate various societal organization' activities that sometimes appear not in accordance with the constitution. There was a societal organization that emerged as a form of expression of freedom euphoria by fighting for ideas through anarchist means. There was also societal organization that was formed for a short-term and had an unclear direction of activities and objectives.

Law no. 17 of 2013 was established to provide comprehensive arrangements related to the issues of societal organization. A societal organization should be formed to be a forum in implementing the freedom of association, assembly, and expression of opinions. A societal organization is also formed in order to participate in the development to achieve the goals of the Unitary State of the Republic of Indonesia based on Pancasila. Then problems arise when there is a societal organization of HTI which was dissolved by the Government, because it is not in accordance with the objectives of the formation of societal organization as outlined in Law No. 17 of 2013. HTI's organizations denied this view and assessed that the Government has violated the right to freedom of association.

Regarding this matter, the effort in dissolving the HTI should not be seen as an effort to limit the human rights of association and assembly. Essentially, such efforts should be seen as an effort to protect the state against the other human rights. This matter is stipulated in the Constitution of Indonesia. Article 28J sections (2) of the 1945 Constitution stipulates that in practicing their rights and freedom both individually and collective, each person should respect other human rights and should not be subject to the restrictions prescribed by a law with the sole intent of ensuring the recognition and respect for the rights and freedoms of others and to fulfil fair demands in accordance with the moral consideration, religious values, securities, and public order in a democracy society. Nevertheless, every steps and government policy as an effort to dissolve the HTI is indeed better to remain in the corridor of applicable law. Law enforcement 
should be carried out in accordance with the provisions of the law, contained in Law No. 17 of 2013.

Legally, the HTI was considered violating the prohibition as stated in Article 59 paragraph (4) of Law No. 17 of 2013 stating that societal prohibited to embrace, develop, and disseminate doctrines or understandings that contradict with the Pancasila. Similarly, Article 21 of Law No. 17 of 2013 on the obligations of Societal organization stipulates that societal organizations should maintain the unity of the nation and the unity of the Unitary State of the Republic of Indonesia, and should maintain public order and the creation of peace in the society.

In the legal framework of Law No. 17 of 2013, if HTI was deemed to violate the regulation, then the HTI may first be subjected to administrative sanctions, in accordance with Article 6o paragraph (1) of Law No. 17 of 2013. There are several administrative sanctions as stipulated in Article 61 of Law No. 17 of 2013, which includes a written warning, termination of assistance and/or grant, temporary suspension of activities, and/or revocation of registered certificate or revocation of legal entity status. Administrative sanctions in the form of written warnings could be issued up to three times if it is not obeyed by the relevant organizations. If the societal organizations does not comply with the third warning, then the Government may impose sanctions in the form of termination of aid and/or grant, and/or suspension of activities. Law No. 17 of 2013 also determines that before imposing administrative sanctions on the violating organization, the Government needs to make persuasive efforts.

Regarding these steps, the Government through the Home Affairs Minister (Mendagri) Tjahjo Kumolo said that the Ministry of Home Affairs actually has given many warnings to HTI, although this statement was denied by the HTI. The HTI spokesperson Ismail Yusanto admitted that his side had never received any written warning or warning letter from the Government. ${ }^{38}$ With regards to the imposition of sanctions on suspension of activities, to a scope of national organizations, the Government should seek legal advice from the Supreme Court, and sanctions for suspension of any activities should be imposed for a maximum

$\overline{3^{8}}$ Republika, May 13, 2017, 1. 
period of six months. It is explicitly regulated in Article 65 and Article 66 of Law No. 17 of 2013. The administrative sanction process in the form of temporary suspension of HTI activities is still unclear whether it has been implemented by the Government or not. The issues on delaying the implementation of this stage is very crucial and become a question for the judges of the district court if the trial is will be exercised. The non-implementation of sanctions imposed by the Government on the HTI may become a mitigating consideration for the defendant.

Regarding this matter, Asep Warlan Yusuf said that the Government must first follow the stages that regulated in the law before proposing the HTI. Without following the stages of dissolution of the organization according to the procedures, the dissolution may be revoked by the judges. Ideally, the Government may propose the dissolution of HTI to the district court if the HTI does not comply with the sanction of activities suspension. The Government may impose sanctions for HTI on their legal entity status after a court decision that already obtained a permanent legal force regarding the dissolution of a legal entity. ${ }^{39}$

Yusril Ihza Mahendra also argued similarly. The Government could not simply dissolve the HTI unless they have given written warning for three times. If the persuasive steps ignored, then the Government could apply for the dissolution of the Societal organization to the court. Yusril also said that organizations with legal status could be revoked of their legal entity status and its registration or in other words it could be dissolved. But it also should be based on the deep study and strong evidences. If not, then the request for the dissolution filed by the Government could be defeated in a court by the HTI's lawyers. ${ }^{40}$

According to Societal Organization Law before it was amended for organizations with legal status like HTI, the sanction is revocation of legal entity status. The revocation of this status should based on a court decision that has obtained a permanent legal force regarding the dissolution of a legal entity. This revocation should take place within 30 (thirty) days from the date of receiving a

39 Kompas, May 17, 2017, 4.

40 "HTI Dibubarkan, Yusril Ihza: Pemerintah Bisa Kalah di Pengadilan", https://nasional.tempo.co/read/ news/2017/05/og/078873547/hti-dibubarkan-yusril-ihza-pemerintah-bisa-kalah-di-pengadilan, 22 May 22, 2017. 
copy of the decision of the dissolution of the Societal Organization which has obtained a permanent legal force by the Minister of Law and Human Rights (Article 68 of Law No. 17 of 2013). The revocation was announced in the State Gazette of the Republic of Indonesia (Article 69 of Law No. 17 of 2013).

Furthermore, the dissolution of organization with legal status is filed by the Prosecutors to the district court upon written request of the Minister of Law and Human Rights. This request must be accompanied by evidence of administrative sanction imposed by the Government. Application for dissolution of Societal Organizations must be decided by a district court within 60 days from the date of the application recorded. The term can be extended to maximum of 20 days with the approval of the Chief Justice of the Supreme Court. The decision of the district court should be submitted to the applicant, the requested, the Minister of Law and Human Rights within seven days from the date of the decision (Article 72 of Law No. 17 of 2013). The verdict of the district court may be filed for a cassation to the Supreme Court with a period of 14 days.

\subsection{New Roles of the Government and the Constitutional Court}

\subsubsection{Government Authority in Dissolving a Societal Organization}

Looking at the complicated and the length of time in the process of dissolving a Societal organization regulated in the Law No. 17 of 2013, the author sees the authority to dissolve the organization should be returned to the Government again. Its dissolution should be given to the Minister of Law and Human Rights for organizations with a legal status, and the Minister of Home Affairs with non-legal status. However, the author constructed that before dissolving Societal organization the government should request consideration from the Constitutional Court as the guardian, and the interpreter of the constitution and Pancasila.

The author assessed that the Law No. 17 of 2013 should be revised related to the arrangement of sanctions, freezing and dissolution. In a limited revision of Law No. 17 of 2013, it also needs to contain the obligation of the Government to take an active role in responding the 
organizations that are no longer in line with the national goals and trample on the Law. This needs to be done to affirm the authority and the ability of the State to be able to regulate, reprimand and discipline some organizations that disobey the applicable Law. Nevertheless, in order that the Government's move will not create new problems, then the efforts in dissolving organizations need take strategic, national, and constitutional steps. The important steps that should be done by the Government are: First, review the existence of societal organizations' caution. Consideration of dissolution of Societal organization must be placed on the national interest, and maintain the sovereignty of the nation and the State. Thus, the dissolution can be done to maintain the integrity of Unitary State of the Republic of Indonesia (NKRI), and to maintain the continuity of constitutional democracy. Second, the Government should analyzed the situation quickly, i.e. create a comprehensive database. It is intended to monitor and evaluate the programs of each existing organizations in Indonesia. The existence of a database can be used to review the actions, cases, and policies of the Societal organization during its establishment, so that it could be used as assessment parameters to improve the activities of organizations that are not in line with the national goals and threatens the integrity of the State. Thus, the Government can make changes to give permits and to dissolve of non-compliance organizations based on the mandate of the Law. Nowadays in the past, the Government was not assertive and less serious in threatening organizations that tried to replace the ideology of Pancasila. Third, after the Government is convinced that there is an organization contrary to the Pancasila, before dissolving the societal organizations, the Government must request a prior consideration to the Constitutional Court as a guardian and the interpreter of the Constitution and Pancasila. 


\subsubsection{Obligation of the Constitutional Court.}

The Constitutional Court has four powers and one obligation. Those authorities are to examine Laws against the Constitution, to decide upon the dispute over the authority of state institutions whose authorities are granted by the Constitution, to decide upon the dissolution of political parties, and to decided disputes concerning the result of general elections. ${ }^{41}$ Its obligation is to provide a decision on the opinion of the People's Representative Council (DPR) regarding constitutional violation by the Presidents and/or Vice President under the Constitution. In addition, the decision of the Constitutional Courtis It means that there is no other legal efforts could be made. ${ }^{42}$

According to Harjono, there is a fine line of the authority of the Constitutional Court in general which could be divided into major powers and additional authorities. The main authorities included (1) Judicial review of the constitutionality of the law against the Constitution; (2) To decide constitutional complaint; (3) To decide dispute over the authority among state institutions; (4) To decided constitutional questions. The Court also has additional authorities that could be vary between countries with one another. ${ }^{43}$ As Harjono said, the author constructs that the obligation of the consideration in the process of dissolution of societal organization can be given additional authority to the Constitutional Court of the Republic of Indonesia.

The 1945 Constitution provides a constitutional basis for the right of freedom of association. Freedom of association is from the human tendency to organize them in order to fight for their rights and interest. Organizational tendencies is to meet the common needs and interest of individuals to achieve common goals based on equality of

${ }_{41}$ Bambang Sutiyoso dan Sri Hastuti Puspitasari, Aspek-Aspek Perkembangan Kekuasaan Kehakiman di Indonesia (Yogyakarta: UII Press, 2005), 49-50.

42 Luthfi Widagdo Eddyono, "Independence of Indonesian Constitutional Court in Norms and Practices", Constituttional Review Journal 3, no. 1, (May 2011): 172.

43 Abdul Rasyid Thalib, Wewenang Mahkamah Konstitusi dan Impilkasinya dalam Sistem Ketatanegaraan Republik Indonesia (Bandung: PT. Citra Aditya Bakti, 2006), 187. 
thought and conscience. In its development, freedom of association becomes one of the universal human rights as a part of human rights. In order to guarantee the establishment of the Constitution as the supreme law of the land, the Constitutional Court was formed as the guardian and the ultimate interpreter of the constitution. ${ }^{44}$ Within this framework, the presence of Constitutional Court as an institution that performs judicial functions is necessary to uphold constitutional justice in Indonesia. With the existence of the Constitutional Court, it is appropriate to give the Court an additional authority in the process of social organizations dissolution, because freedom of association through Societal organization is a constitutional right of the citizen guaranteed in the 1945 Constitution. To the deviations from the constitutional rights of the citizens, the Constitutional Court is entitled to carry out an assessment with its function, which is to interpret and guard the Constitution. ${ }^{45}$ In other words, the Constitutional Court is in charge to maintain the constitutionality of law concerning the implementation of the right of association by every citizen.

The author drew upon the Constitutional Court's experience in exercising the authority to review the law against the 1945 Constitution. In some of its legal considerations, the laws were not only reviewed against the 1945 Constitution but also Pancasila. The Constitutional Court concluded that the reviewed law directly opposed to Pancasila even though the applicant did not mention this arguments. ${ }^{46}$ This standing was reinforced from the statement by the Chief Justice of the Constitutional Court of 2008-2013, Moh. Mahfud MD who stated that the majority of laws were annulled by the Constitutional Court because it violated the Pancasila values.

44 Jimly Asshiddiqie, dan Ahmad Syahrizal, Peradilan Konstitusi di Sepuluh Negara (Jakarta: Konstitusi Press, 2006), 135-152.

45 A.M. Fatwa, Potret Konstitusi Pasca AmandemenUUD 1945 (Jakarta: Kompas Media Nusantara, 2009).

${ }_{46}$ In Decision Number 100/PUU-XI/2013, The Constitutional Court states that the Constitutional Court not only serves as the guardian of the Constitution, but also the guardian of ideology, namely Pancasila. 
Pancasila is an ideology, philosophy of life, ${ }^{47}$ and the crystallization noble views consisting full of ethical and moral values as well as in accordance with the personality of the Indonesia people. Therefore, it is a certainty that the implementation of Pancasila can be carried out in every area in the life of nation and state of Indonesia by formulating a concept of national implementation based on Pancasila. ${ }^{8}$ Moreover, in Article 2 of Law No. 12 of 2011 on the Establishment of Laws and Regulation, Pancasila is considered as a staatsfundamentalnorm and the source of all legal sources of the State.

The Constitutional Court has a strategic position to institutionalize Pancasila's values through its decisions. This must be done by the Court to safeguard the purity and power of Pancasila. In many decisions, the Constitutional Court had imposed Pancasila's value. Accordingly, the Government may request consideration to the Constitutional Court if the presence of an organization whose actions and ideologies are contrary to the 1945 Constitution. If the consideration of the Constitutional Court states that an ideology of an organization and its work is contrary to Pancasila, the Government must act strictly, to dissolve organization that commit violence, hostilities, and significantly threaten the integrity of the nation and the unity of the nation. Thus, Pancasila would no longer be the only rhetorical-semantic sentences without knowing how to descend to the earth, but could manifest itself in the midst of national and state life as the basic principle and guidance in the organization.

Ideally, dissolving a societal Organization that contrary to the Pancasila shall be done by the Government. The consultation mechanisms that have been initiated by the writers could become concrete steps to realize the quality of the restriction of the independence of the association, and constitutional assembly because its purpose is not only to create a democratic legal state in accordance with the Constitution, but also to

\footnotetext{
As'ad Said Ali, Negara Pancasila: Jalan Kemashlahatan Berbangsa (Jakarta: Pustaka LP3ES, 2009), 15.
}

$4^{8}$ Yudi Latief, Pancasila Sakti, Jakarta: Gatra, Edition Number. 48 Tahun XVII, October 2011, 106. 
put forward the principles of time efficiency. Some important things to be aware of are when the consultation mechanism is executed against the dissolution of organizations, at least some aspects that should be used as references are as follows: first, the consultation mechanism shall be executed before the dissolution of organizations. It is intended to avoid the indirect consequences in the form of the loss in the Government's function to issue a final, individual and concrete decision of the state administration official (KTUN) so that there would be no assumption of reducing the essence of KTUN as an executive product.

Second, the Constitutional Court is limited only to provide views relating to the constitutionality and technical juridical dissolution of Societal organization. This means that the Constitutional Court role is only limited to provide inputs to each question raised by the government. If there is an important dimension that according to the Constitutional Court is needed to be given an input, but not included in the manifest that was consulted to the Constitutional Court, then the Court should not have to answer it. Thus, the Constitutional Court will not go too far in the process of dissolution.

Third, the Constitutional Court opinion on the outcome of the consultation should not have a permanent legal force and not as a form of final legal effort. However, in this case, the Constitutional Court opinions is only a recommendation. This means that the government could still ignore it or comply with it, so the fear of consultation mechanisms could bring its constitutional "label" that had been unified and inherent in the process of Societal organization dissolution could be avoided.

\section{CONCLUSION}

The obligation of societal organization to ideology Pancasila was a limitation of rights and freedom based on the principles of the applicable law in Indonesia. The legislator still sees Pancasila as a plenary ideology for the principle of societal organization. 
Persuasive efforts must be done first before the imposition of administrative sanctions if the Government.

The author constructed the authority of the Government in the dissolution of non-absolute Societal organization as stipulated in Law No. 8 of 1985 where the Government prior to dissolving Societal Organization should request consideration of the Constitutional Court as a guardian and the interpreter of the Constitution and Pancasila.

\section{BIBLIOGRAPHY}

Ali, As'ad Said: Negara Pancasila: Jalan Kemashlahatan Berbangsa: Jakarta: Pustaka LP3ES, 2009.

Alrasid, Harun: Naskah UUD 1945 Sesudah Empat Kali Diubah oleh MPR: Jakarta: Universities Indonesia (UI-Press), 2007.

Amin, SM, Demokrasi Selayang Pandang, Jakarta: Pradnya Paramita, 1976.

Asshiddiqie, Jimly, dan Syahrizal, Ahmad, Peradilan Konstitusi di Sepuluh Negara: Jakarta: Konstitusi Press, 2006.

Azhary, Muhammad Tahir: Beberapa Aspek Hukum Tata Negara, Hukum Pidana, dan Hukum Islam: Menyambut 73 Tahun Prof. Dr. H. Muhammad Tahir Azhary, S.H., Akademisi, Praktisi, dan Politisi: Jakarta: Kencana Prenada Media Group, 2012.

Bagus, Lorens: Kamus Filsafat: Jakarta: Gramedia Pustaka Utama, 200.

Bahar, Saafroedin, et.al, (Ed): Risalah Sidang Badan Penyelenggara Usaha Persiapan Kemerdekaan Indonesia (BPUPKI)-Panitia Persiapan Kemerdekaan Indonesia (PPKI) 28 Mei 1945-22 Agustus 1945. Jakarta: Sekretariat Negara Republik Indonesia, 1995.

Bell, Daniel. Matinya Ideologi. Magelang: Indonesia Tera, 2001.

Eddyono, Luthfi. "Independence of Indonesian Constitutional Court in Norms and Practices." Constitutional Review Journal 3, no. 1 (May 2017). 
Faiz, Pan Mohamad. "The Protection of Civil and Political Right by the Constitutional Court of Indonesia." Indonesian Law Review Journal 6, no.2 (May-August 2016).

Fatwa, A.M. "Potret Konstitusi Pasca Amandemen UUD 1945." Kompas Media Nusantara, 2009.

Hadjon, Philipus M: Perlindungan Hukum Bagi Rakyat di Indonesia: Surabaya: Bina Ilmu, 1987.

Indonesia, 1945 Constitution of the State of the Republic of Indonesia. , Law No.8 of 1985 on Societal Organization. , Law No. 17 of 2013 on Societal Organization. , Government Regulation No. 18 of 1986 on the implementation of Law No. 8 of 1985 on Societal Organizations.

Kania Winayanti, Nia: Dasar Hukum Pendirian dan Pembubaran Ormas (Organisasi Kemasyarakatan): Yogyakarta: Pustaka Yustisia, 2011. , "Makna Pasal 28 UUD 1945 terhadap Kebebasan Berserikat dalam Konteks Hubungan Industrial." Jurnal Konstitusi 8, no.6 (2011).

Kartodihardjo, Soewargo: Asas-Asas Hukum Tata Negara: Yogyakarta: Fakultas Hukum Universitas Gajah Mada, 1983.

Latie, Yudi. "Pancasila Sakti." Gatra, October, 2011.

Marzuki, Suparman, et.al: Hukum Hak Asasi Manusia: Yogyakarta: Pusat Studi Hak Asasi Manusia Universitas Islam Indonesia, 2008.

MD, Moh. Mahfud: Politik Hukum di Indonesia. Jakarta: Rajawali Pers, 2010. "Memproteksi NKRI", Media Indonesia, 15 Mei 2017.

Mertokusumo, Sudikno: Penemuan Hukum: Sebuah Pengantar: Yogyakarta: Liberty, 2009.

n.d. "HTI DIbubarkan, Yusril Ihza: Pemerintah Bisa Kalah di Pengadilan," Tempo, Mei 22, 2017. 
nd. "Pemerintah Diadukan ke Komnas HAM." Republika, May 13, 2017.“

nd. "Pemerintah Tak Akan Kompromi." Kompas, May 13, 2017.

nd. "Pemerintah Harus Ambil Langkah Cepat." Kompas, May 17, 2017.

Nugroho, Riant D: Kebijakan Publik, Formulasi, Implementasi dan Evaluasi: Jakarta: Elex Media Komputindo, 2003.

Perwira, Indra: Pembatasan Hak Berserikat, dan Berkumpul, Article, No Year, and No Publisher.

Priyanto, At. Sugeng: Dinamika Ideologi Partai Politik Keagamaan Pada Masa Orde Baru: Yogyakarta: Magnum Pustaka Utama, 2015.

RI, Departemen Pendidikan, dan Kebudayaan, Direktorat Jenderal Pendidikan Tinggi, UUD 1945, P4, GBHN, TAP-TAP MAPR 1983, Pidato Pertanggungjawaban Presiden/Mandataris, Bahan Penataran, dan Bahan Referensi Penataran. Jakarta: Direktorat Jenderal Pendidikan Tinggi Departemen Pendidikan, dan Kebudayaan, 1984.

RI, Dewan Perwakilan Rakyat, Catatan Panitia Khusus Lima Rancangan UndangUndang Tentang Politik, Tanggal 10 Januari 1985, Jakarta: Sekretariat Jenderal DPR RI, 1985.

Catatan Panitia Khusus Lima Rancangan UndangUndang Tentang Politik, Tanggal 11 Januari 1985, Jakarta: Sekretariat Jenderal DPR RI, 1985.

Catatan Rapat Panitia Khusus Lima Rancangan Undang-Undang Partai Politik, dan Golongan Karya, Tanggal 4 Februari 1985, Jakarta: Sekretariat Jenderal DPR RI, 1985.

Romli, Lili: Islam Yes Partai Islam Yes: Sejarah Perkembangan Partai-Partai Islam di Indonesia: Yogyakarta: Pustaka Pelajar dengan Pusat Penelitian Politik LIPI, 2006.

Safaat, Muchamad Ali. "Pembubaran Partai Politik di Indonesia." Ph.D Diss., University of Indonesia, 2009. 
Soehino: Ilmu Negara: Liberty: Yogyakarta, 1980.

Sutiyoso, Bambang, dan Puspitasari, Sri Hastuti: Aspek-Aspek Perkembangan Kekuasaan Kehakiman di Indonesia: Yogyakarta: UII Press, 2005.

Thalib, Abdul Rasyid: Wewenang Mahkamah Konstitusi dan Implikasinya dalam Sistem Ketatanegaraan Republik Indonesia: Bandung: PT Citra Aditya Bakti, 2006.

Wahjono, Padmo: Indonesia Negara Berdasarkan Atas Hukum: Jakarta: Yudhistira Ghalia Indonesia, 1983. 